\title{
Combining Ability and Gene Action for Grain Yield and Its Component Traits in Yellow Grained Single Cross Hybrids of Maize (Zea mays L.)
}

\author{
Ram Bhupal Choudhary*, Shailesh Marker, Indranil Battacharjee and Ramnath
}

Experimentation Centre of Department of Genetics and Plant Breeding, Allahabad School of Agriculture, Sam Higginbottom University of Agriculture, Technology and Sciences, Allahabad-211006, U.P., India

*Corresponding author

\section{A B S T R A C T}

Keywords

Maize (Zea mays L.), Combining ability, Gene action and grain yield

Article Info

Accepted:

10 July 2018

Available Online:

10 August 2018
Five maize inbred lines and their 10 direct crosses produced through half-diallel scheme were evaluated with two checks during kharif-2014 for grain yield and its component traits. The crosses namely JP25 W95 $\times$ CM-138 and CML-439 $\times$ CM-138 recorded higher level of economic heterosis for grain yield. Combining ability analysis suggested the preponderance of non-additive gene action for majority of the traits viz., grain yield, 100kernel weight, ear length, ear girth and number of grain rows per cob. Out of the five parents, namely CM-138, CML-439 and JP25 W95 recorded significant general combining ability effects in desirable direction for grain yield and its component traits. The crosses JP25 W95 $\times$ CM-138 and CML-439 $\times$ CM-138 recorded significant SCA effects for grain yield and 100-kernel weight. The parents CM-138, CML-439 and JP25 W95 can be used for development of superior transgressive hybrids.

\section{Introduction}

Maize (Zea mays L.; $2 \mathrm{n}=20$ ) is an important cereal crop of India, which plays an important role in human and animal nutrition. Maize grain is being mainly used for feed (63\%), food (23\%) and industrial purpose (13\%). Maize is known as "Queen of cereals" because of its high production potential and wider flexibility. Yield in maize crop has increased considerably over the years as breeders are successful in exploite the heterosis or hybrid vigour. This indicates the importance of maize in ever increasing need for food and warrants continuous development of new high yielding hybrids. Hybrid breeding method for attaining maximum genetic gain from the effects of heterosis. The degree of heterosis depends on the relative performance of parents and their corresponding hybrids. The commercial production of hybrids however, depends upon two factors viz., performance of line itself and performance of line in hybrid combination. The performance of line in hybrid combination is determined through the assessment of general combining ability (GCA) and Specific combining ability (SCA) effects. Diallel analysis is considered to be an accurate method for the estimation of combining ability and also it provides information on the nature of gene action of the characters. This approach has practical utility 
in identifying the superior lines along with their heterotic effects which in turn can be utilized for genetic improvement of yield. The value of any population depends on its potential per se and it's combining ability in crosses (Vacaro, et al., 2002). The objective is to estimate the heterosis, heterobeltiosis and standard heterosis for grain yield and to find out the best general combining parents for grain yield based on GCA effects and to estimates specific combining ability effects for quantitative characters in maize.

\section{Materials and Methods}

Five inbred lines DMR-N4, CM-138, CML439, JP 25 W95 and POP 31 Q 18211 used to raise $10 \mathrm{~F}_{1} \mathrm{~s}$ by using diallel fashion excluding reciprocals during rabi-2013. In, kharif-2014, $\mathrm{F}_{1} \mathrm{~s}$, parents and standard checks were evaluated at Field Experimentation Centre of the Department of Genetics and Plant Breeding, Allahabad School of Agriculture, Sam Higginbottom University of Agriculture Technology and Sciences, Allahabad (U.P.), in a randomized block design with three replications. The experimental material was raised in single row of $5.0 \mathrm{~m}$ each and with spacing of $60 \times 20 \mathrm{~cm}$. Observations were recorded on five randomly chosen 5 plants for five characters viz., ear length $(\mathrm{cm})$, ear girth (cm), number of kernel rows/ear, 100-kernel weight $(\mathrm{g})$ and grain yield per plant $(\mathrm{g})$ were subjected to analysis of variance according to experimental design. The variance for GCA and SCA were tested against their respective error variance derived from Anova reduced to mean level. Significant test for combining ability effects (GCA and SCA) were performed using t-test. The estimates of combining ability effects were worked out using (Griffing (1956) Method-(II), Model-(I).

\section{Results and Discussion}

Percent heterosis over mid parent, better and best check were estimated to know the possible gene action as well as to exploit heterosis for grain yield and its component traits. Superior single cross hybrids operate through the phenomenon of heterosis are the important need to modern agriculture (Vasal et al., 1995). In the present investigation, analysis of variance revealed significant variability among the parental lines and their hybrids for majority of traits (Table 1).

These results are in agreement with the findings of Langade et al., (2013), Vijayan et al., (2014) and Kumar et al., (2015). The Heterosis over mid parent, better parent and best check for grain yield per plant among top five heterotic crosses ranged from $39.11 * *$ to $70.51^{* *}, 37.91 * *$ to $62.72 * *$ and $37.91^{* *}$ to $60.50 * *$ percent respectively (Table 2 ).

A perusal of top five heterotic crosses for grain yield revealed that single cross hybrid (JP 25 W 95 x CM-138) exhibited highest positive significant Heterosis over mid parent (67.37 percent), better parent (60.50 percent) and best check (60.50 percent) respectively.

This hybrid also posses good per se performance for grain yield (90.82 g/plant), 100-kernel weight (25.73 g), ear length (16.75 $\mathrm{cm})$, ear girth $(12.51 \mathrm{~cm})$ and number of kernel rows per ear (13.67). Top five heterotic crosses exhibited positive significant Heterosis at all three levels, indicating preponderance of non-additive gene action in the expression of grain yield and it's contributing traits (Table 2 ). The results for Heterosis in maize for yield and it's contributing traits are in conformity with the findings of Chahar et al., (2013) and Khan et al., (2014).

\section{General combininig ability effects}

The estimates of General combining ability (GCA) effects of the parents for different characters are presented in Table 3. A wide range of variability among the parents for different characters. 
Table.1 Analysis of variance for different characters in a diallel cross of maize Mean squares

\begin{tabular}{|c|c|c|c|c|c|c|c|}
\hline $\begin{array}{l}\text { S. } \\
\text { No. }\end{array}$ & Source of variation & d.f. & Grain yield per plant & $\begin{array}{c}\text { 100-kernel } \\
\text { weight }\end{array}$ & Ear length & Ear girth & $\begin{array}{c}\text { Number of } \\
\text { kernel } \\
\text { rows/ear }\end{array}$ \\
\hline 1. & Replications & 2 & 11.60 & 0.23 & 1.03 & 0.21 & 0.15 \\
\hline 2. & Genotypes & 14 & $668.84 * *$ & $74.46 * *$ & $5.99 * *$ & $1.57 * *$ & $1.27 *$ \\
\hline 3. & Parents & 4 & $29.64 *$ & $25.21 * *$ & $1.75 *$ & 0.17 & 0.83 \\
\hline 4. & Crosses & 9 & $274.63 * *$ & $20.61 * *$ & $1.57 *$ & $0.55 * *$ & $1.61 *$ \\
\hline 5. & Parent vs Crosses & 1 & $6773.52 * *$ & $756.14 * *$ & $62.68 * *$ & $16.35 * *$ & 0.04 \\
\hline 6. & Error & 28 & 9.08 & 1.23 & 0.35 & 0.08 & 0.44 \\
\hline
\end{tabular}

$* *$ and $*$ Significant at $1 \%$ and $5 \%$ respectively.

Table.2 Best hybrids identified on the basis of economic Heterosis for grain yield per plant along with their per se performance

\begin{tabular}{|c|c|c|c|c|c|c|c|c|c|}
\hline \multirow{2}{*}{ S. No. } & \multirow{2}{*}{ Hybrid } & \multirow{2}{*}{$\begin{array}{l}\text { Heterosis } \\
\text { (Ha) }\end{array}$} & \multirow{2}{*}{$\begin{array}{c}\text { Hetero } \\
\text { beltiosis } \\
\text { (Hb) }\end{array}$} & \multirow{2}{*}{$\begin{array}{l}\text { Economic } \\
\text { Heterosis } \\
\quad(\mathrm{Hc})\end{array}$} & \multicolumn{5}{|c|}{ Per se performance } \\
\hline & & & & & $\begin{array}{l}\text { Grain yield/ } \\
\text { Plant (g) }\end{array}$ & $\begin{array}{l}\text { 100-kernel } \\
\text { weight (g) }\end{array}$ & $\begin{array}{l}\text { Ear length } \\
\quad(\mathrm{cm})\end{array}$ & $\begin{array}{l}\text { Ear girth } \\
(\mathrm{cm})\end{array}$ & $\begin{array}{c}\text { Number of } \\
\text { kernel } \\
\text { rows/ear }\end{array}$ \\
\hline 1 & JP 25 W 95 X CM-138 & $67.37 * *$ & $60.50 * *$ & $60.50 * *$ & 90.82 & 25.73 & 16.75 & 12.51 & 13.67 \\
\hline 2 & CML-439 × CM-138 & $68.26 * *$ & $62.72 * *$ & $59.90 * *$ & 90.48 & 25.67 & 16.14 & 12.13 & 13.33 \\
\hline 3 & JP 25 W $95 \times$ DMR-N4 & $62.27 * *$ & $58.84 * *$ & $58.84 * *$ & 89.88 & 22.57 & 15.14 & 11.98 & 12.33 \\
\hline 4 & $\begin{array}{l}\text { JP } 25 \text { W } 95 \text { × CML- } \\
439\end{array}$ & $39.11 * *$ & $37.91 * *$ & $37.91 * *$ & 88.96 & 24.82 & 16.05 & 12.08 & 13.00 \\
\hline \multirow[t]{2}{*}{5} & $\begin{array}{l}\text { POP } 31 \text { Q } 18211 \times \\
\text { CML439 }\end{array}$ & $70.51 * *$ & $59.98 * *$ & $57.21 * *$ & 78.05 & 24.11 & 15.97 & 12.02 & 12.67 \\
\hline & Checks & & & & & & & & \\
\hline 6 & Kaveri Super-2020 & & & & 85.36 & 21.71 & 15.80 & 11.39 & 12.66 \\
\hline 7 & DHS-42 & & & & 44.09 & 16.02 & 11.37 & 11.08 & 12.00 \\
\hline
\end{tabular}


Table.3 General combining ability effects for different characters in maize

\begin{tabular}{|r|l|c|c|c|c|c|}
\hline $\begin{array}{c}\text { S. } \\
\text { No }\end{array}$ & \multicolumn{1}{|c|}{ Genotypes } & $\begin{array}{c}\text { Ear } \\
\text { length }\end{array}$ & $\begin{array}{c}\text { Ear } \\
\text { girth }\end{array}$ & $\begin{array}{c}\text { Number } \\
\text { of kernel } \\
\text { rows/ear }\end{array}$ & $\begin{array}{c}\text { Test weight } \\
(100 \text { kernel } \\
\text { weight })\end{array}$ & $\begin{array}{c}\text { Grain } \\
\text { yield/pl } \\
\text { ant }\end{array}$ \\
\hline 1 & DMR-N4 $\left(\mathrm{P}_{1}\right)$ & $\mathbf{- 0 . 2 3}$ & $\mathbf{- 0 . 2 4 * *}$ & $\mathbf{- 0 . 5 3 * *}$ & $\mathbf{- 1 . 4 6 * *}$ & $\mathbf{- 2 . 1 5 *}$ \\
\hline 2 & CM-138 $\left(\mathrm{P}_{2}\right)$ & $\mathbf{0 . 0 5}$ & $\mathbf{- 0 . 0 0 6}$ & $\mathbf{0 . 0 8}$ & $\mathbf{- 0 . 6 8 *}$ & $\mathbf{- 0 . 1 2}$ \\
\hline 3 & CML-439 $\left(\mathrm{P}_{3}\right)$ & $\mathbf{0 . 0 7}$ & $\mathbf{0 . 0 9}$ & $\mathbf{0 . 0 3}$ & $\mathbf{0 . 6 9 *}$ & $\mathbf{2 . 2 9 * *}$ \\
\hline 4 & JP 25 W 95 $\left(\mathrm{P}_{4}\right)$ & $\mathbf{0 . 4 2} * *$ & $\mathbf{0 . 1 4}$ & $\mathbf{0 . 3 7} *$ & $\mathbf{2 . 1 4} * *$ & $\mathbf{2 . 8 3 * *}$ \\
\hline 5 & POP 31 Q 18211 $\left(\mathrm{P}_{5}\right)$ & $\mathbf{- 0 . 3 1 *}$ & $\mathbf{0 . 0 1}$ & $\mathbf{0 . 0 3}$ & $\mathbf{- 0 . 6 9 *}$ & $\mathbf{- 2 . 8 4 * *}$ \\
\hline
\end{tabular}

$* *$ and $*$ Significant at $1 \%$ and $5 \%$ respectively.

Table.4 Specific combining ability effects for different characters in maize

\begin{tabular}{|c|c|c|c|c|c|c|}
\hline $\begin{array}{l}\text { S. } \\
\text { No }\end{array}$ & Genotypes & $\begin{array}{c}\text { Ear } \\
\text { length }\end{array}$ & $\begin{array}{l}\text { Ear } \\
\text { girth }\end{array}$ & $\begin{array}{l}\text { Number } \\
\text { of kernel } \\
\text { rows/ear }\end{array}$ & $\begin{array}{l}\text { Test weight } \\
\text { (100 seed } \\
\text { weight) }\end{array}$ & $\begin{array}{l}\text { Grain } \\
\text { yield/ } \\
\text { plant }\end{array}$ \\
\hline 1 & CM-138 × DMR-N4 & $1.44 * *$ & -0.19 & -0.17 & -0.44 & -2.45 \\
\hline 2 & CML-439 × DMR-N4 & -0.15 & -0.008 & $-1.12 *$ & $4.24 * *$ & 1.05 \\
\hline 3 & JP 25 W $95 \times$ DMR-N4 & 0.16 & $0.62 *$ & -0.12 & $1.78 *$ & $18.43 * *$ \\
\hline 4 & POP 31 Q $18211 \times$ DMR-N4 & $1.62 *$ & $0.85 * *$ & 0.54 & $2.21 *$ & $7.48 * *$ \\
\hline 5 & CML-439 × CM-138 & $1.22 *$ & $0.57 *$ & 0.58 & $5.54 * *$ & $17.55 * *$ \\
\hline 6 & JP 25 W $95 \times$ CM-138 & $1.48 * *$ & $0.91 * *$ & 0.58 & $4.16^{* *}$ & $17.35 * *$ \\
\hline 7 & POP 31 Q $18211 \times$ CM-138 & 0.17 & $0.47 *$ & -0.07 & $2.79 * *$ & $4.67 *$ \\
\hline 8 & JP 25 W $95 \times$ CML-439 & $0.68 *$ & 0.31 & -0.03 & 1.16 & 2.14 \\
\hline 9 & POP 31 Q $18211 \times$ CML-439 & $1.49 * *$ & 0.50 & -0.03 & $4.70 * *$ & $18.74 * *$ \\
\hline 10 & POP 31 Q $18211 \times$ JP 25 W 95 & 0.20 & 0.20 & -0.36 & $2.81 * *$ & 1.75 \\
\hline
\end{tabular}

** and $*$ Significant at $1 \%$ and $5 \%$ respectively.

Table.5 Top ranking best (first 2) cross combinations identified for yield and yield components based on per se and SCA effects

\begin{tabular}{|c|c|c|c|c|}
\hline $\begin{array}{l}\text { S. } \\
\text { No }\end{array}$ & Character & Cross combinations & $\begin{array}{c}\text { Per se } \\
\text { performance }\end{array}$ & $\begin{array}{c}\text { Sca } \\
\text { effects }\end{array}$ \\
\hline \multirow[t]{2}{*}{1} & \multirow[t]{2}{*}{ Grain yield/plant } & POP31Q18211 X CML-439 & 89.88 & $18.74 * *$ \\
\hline & & JP25W95 X DMR-N4 & 88.96 & $18.43 * *$ \\
\hline \multirow[t]{2}{*}{2} & \multirow{2}{*}{$\begin{array}{l}\text { Test weight (100- } \\
\text { kernel weight) }\end{array}$} & CML-439 X CM-138 & 25.67 & $5.54 * *$ \\
\hline & & POP31Q18211 X CML-439 & 24.82 & $4.70 * *$ \\
\hline \multirow[t]{2}{*}{3} & \multirow[t]{2}{*}{ Ear length } & POP31Q18211 X DMR-N4 & 15.87 & $1.62 * *$ \\
\hline & & POP31Q18211 X CML-439 & 16.05 & $1.49 * *$ \\
\hline \multirow[t]{2}{*}{4} & \multirow[t]{2}{*}{ Ear girth } & JP25W95 X CM-138 & 12.51 & $0.91 * *$ \\
\hline & & POP31Q18211 X DMR-N4 & 12.08 & $0.85 * *$ \\
\hline \multirow[t]{2}{*}{5} & \multirow{2}{*}{$\begin{array}{l}\text { Number of kernel } \\
\text { row per ear }\end{array}$} & JP25W95 X CM-138 & 13.67 & 0.58 \\
\hline & & CML-439 X CM-138 & 13.33 & 0.58 \\
\hline
\end{tabular}


Among the lines, JP25 W 95 exhibited high positive significant GCA effect of $2.83(\mathrm{~g})$ followed by CML-439 2.29 (g) for grain yield per plant. The GCA effects are important indicators of the value of inbreds in hybrid combinations. It was observed from the GCA effect that, none of the parent individually expressed good general combiners for all the characters. The high and positive significant GCA effects suggested that line JP25 W 95 and CML-439 lines are the best general combiner for grain yield per plant along with yield contributing characters viz., 100-kernel weight, number of kernel rows/ear, ear length and ear girth. The results for General combining ability in maize for yield and it's contributing traits are in conformity with the findings of Devi et al., (2012) and Kapoor et al., (2014).

\section{Specific combininig ability effects}

The estimation of SCA effects of maize are presented in Table 4. High and positive SCA effect is desirable for grain yield, 100-seed weight, ear length, ear girth, number of kernel rows per ear. Both positive and negative significant SCA effects were observed among the crosses for grain yield per plant Table 4 . Among the 10 cross combinations, the cross POP 31Q 18211xCML-439, JP 25 W $95 \times$ DMR-N4, CML-439 $\times$ CM-138 and JP 25 W $95 \times \mathrm{CM}-138$ were good specific combiners. High SCA effects of the crosses indicate that deviation from the what would have been predicted based on their parental performances. These crosses with high positive and significant estimates of SCA effect could be selected for their specific combining ability to use in maize improvement. These results are agreement with the findings of Jawahar et al., (2012) and Mahesh et al., (2013).

Best 2 crosses for grain yield per plant, 100kernel weight, ear length, ear girth and number for kernel rows per ear with high per se performance along with desirable SCA effects of crosses are listed in Table 5. Two crosses i.e., POP31Q18211 X CML-439 and JP25W95 X DMR-N4 showed higher performance for grain yield per plant along with high positive significant SCA effects. Among them POP31Q18211 X CML-439 $(89.88 \mathrm{~g})$ expressed higher per se performance along with maximum SCA effects for grain yield per plant $(18.74 \mathrm{~g})$.

The gca effects of inbreds and sca effects of their hybrid combinations indicated that the crosses with high sca effects were resulted due to all possible parental gca combinations i.e. high $\times$ high, high $\times$ low, low $\times$ high and low $\times$ low. Therefore, one can afford to include some low general combiners also along with good combiners in breeding programmes where hybridization is involved.

\section{References}

Chahar, S., Vyas, M., Ranwah, B. R. and Gopal V. (2014). Heterosis and combining ability analysis for yield and its contributing traits in early maturing maize (Zea mays L.) genotypes. Trends in Biosciences 7 (14): 1774:1777.

Devi, P. and Singh, N. K. (2011). Heterosis, molecular diversity, combining ability and their interrelationships in short duration maize (Zea mays L.) across the environments. Euphytica 178:71-81

Elton Vacaro, Jose Fernandes Barbosa Neto, Diego Girardi Pegoraro, Claudio Natalino Nuss and Leo Duc Haa Conceicao (2001). Combining ability of twelve maize populations. agropec. bras., Brasília, 37(1), pp. 67-72.

Hull, F. H. (1945). Recurrent selection for specific combining ability in corn. Journal Amer. Society of Agronomy, 36: 234-245. 
Jawaharial, J., Lakshmikantha, R. And Kumar, R. S. (2012). Heterosis for yield and yield component traits in maize (Zea mays L.) India Journal of Agriculture Research, 46 (2): 184-187.

Kapoor, C., Lata, S. And Sharma, J. K. (2014). Combining ability and Heterosis studies for grain yield and its component traits in maize (Zea mays L.). Electronic Journal of Plant Breeding, 5 (4): 716-721.

Khan, R., Dubay, R. B., Vadodariya, G. D. and Patel, A. I. (2014). Heterosis for quantitative and quality traits in maize (Zea mays L.). Trends in Biosciences 7 (6): 422-424.

Kumar, B., Razdan, A. K. and Pandey, S. K. (2015). Combining ability analysis for grain yield and component traits in yellow maize single crosses. Bioinfolet 12 (1A): 14-18.

Langade, D. M., Shahi, J. P., Kumar, P. and Sharma, A. (2013). Estimation of Heterosis for Yield and Yield attributing traits in Diallel Crosses of
Maize. Trends in Biosciences 6 (6): 719-722.

Mahesh, N., Wali, M.C., Gowda, M.V.C., Motagi, B.N. and Nagaratna (2013).Genetic analysis of grain yield, Starch, protein and oil content6 in single cross hybrids of maize. Karnataka Journal of Agriculture Sciences, 26 (2): 185-189.

Shull, G. H. (1908). The composition of field of maize. American Breeders Association Reports, 4: 296-301.

Vasal, S.K., Spreinivasion, G., Crossa, J. and beck, D.L. (1992). Heterosis and combining ability of CIMMYT subtropical and temperate early, maturity maize germplasm. Crop Sciences, 32: 884-890.

Vavilov, N.I. (1951). Phytogeographic basis of plant breeding. The origin, variation, immunity and breeding of cultivated plants. Chronica Botanica. 13: 1-36.

Vijayan, R. and Kalamani, A. (2014). Heterosis analysis in tolerant maize (Zea mays L.) hybrids. Bioinfolet, 11 (2A): 394-398.

\section{How to cite this article:}

Ram Bhupal Choudhary, Shailesh Marker, Indranil Battacharjee and Ramnath. 2018. Combining Ability and Gene Action for Grain Yield and Its Component Traits in Yellow Grained Single Cross Hybrids of Maize (Zea mays L.). Int.J.Curr.Microbiol.App.Sci. 7(08): 1666-1671. doi: https://doi.org/10.20546/ijcmas.2018.708.191 